Diana Hincu

University Lecturer

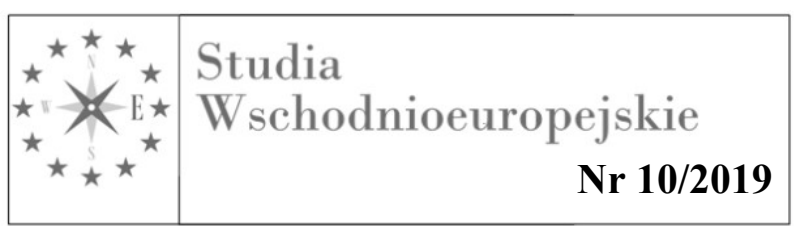

\title{
Mainstreaming Migration into Development: Moldova's experience and potential in engaging its Diaspora
}

$\mathrm{M}$ oldova is primarily a country of origin of migration and at some extent a transit country for migrants. Confronted with political instability, rapidly rising unemployment and collapsing incomes, people began emigrating from Moldova on a large scale in the first half of the 1990s. The emigration in 1990-2000 was constrained by extreme poverty, high rate of illegal crossing of the border and problems with trafficking in human beings. The total number of migrants abroad ranges from 800.000 - $1 \mathrm{mln}$. according different sources. The period after Moldova obtained its independence in 1991 is marked by severe brain drain and the intensity of the permanent (leaving for permanent residence abroad or repatriation of Moldovan citizens), as well as by the temporary external migration (for work, education, family reunification and other purposes). In both cases, the migration balance is negative. One of the major challenges for the country is the temporary labour emigration, which by its scale and features cause lasting negative effects on the economic, social and demographic development of the country. In 2019, the total population of Moldova was recorded as being 2681734 inhabitants (from 4.5. million back in 2003)297 and according to the UN projections, Moldova's population will decrease to 2 million inhabitants by 2100298 . Although the migration processes involved mainly men $66 \%$ of the total number of migrants, the number of women is disturbingly large $-34 \%$. The share of young people went abroad, in particular those of the age group 20-24 years old, is alarmingly high.299

The main push factor for Moldovan migrants is economic: poverty, lack of adequate employment opportunities and low salaries, while higher living standards abroad act as a pull factor. Respectively, the economy of the country, has expanded by an average of $5 \%$ annually, driven by consumption and fueled by remittances. The remittances from Moldova abroad account for a quarter of GDP, among the highest share in the world (being $26 \%$ of the GDP and exceed 7.7 times the net value of the foreign direct investments)300. The visa-free regime with EU (2014) turned out to be another channel for Moldova's population labour migration. Many Moldovan citizens that have entered the EU by a biometric passport would get employed illegally, filling in for their co-nationals that go back to Moldova or Ukraine on vacation or for medical treatment. Labour migration prevails ( $72 \%)$ and Moldovan migrants work in economic sectors where labour force is in demand - community, social and personal services $(33 \%)$, construction $(20 \%)$, household management services (13\%).

\footnotetext{
297 Data provided by National Statistics Bureau of Moldova on population and demographic situation in the country, za: https://statbank.statistica.md/pxweb/pxweb/en/ (05.11.2019).

298 World Population Prospects 2019 presented by UN, za: https://population.un.org/wpp/Graphs/Probabilistic/POP/TOT/498 (07.11.2019). 299 National Strategy on Migration and Asylum for 2011-2020, za: www.bma.gov.md. (07.11.2019).
}

300 Remittances on track to become the largest source of external financing in developing countries, World Bank, za: https://www.worldbank.org/en/country/moldova (06.11.2019). 
The recent trends of migration include: 1) short-term labour migration to the Russian Federation and other CIS countries and 2) increasing long-term migration to the EU (mainly Italy, Spain, Portugal and Poland). It could also be observed that educational migration is growing; the importance of family reunification increases; children and parents of migrants are increasingly and massively reunited with their able-bodied family members in the countries of destination.

\section{Moldovan Diaspora: snapshot}

Moldovan Government started to acknowledge that migration could be a phenomenon able to produce not only negative social costs, but also positive development endings for the country. This awareness led to important legislative and policymaking interventions. The National Development Strategy "Moldova 2020" for the first time revealed expressly the migration importance for development, because the trends related to the economic growth and poverty reduction in Moldova are closely correlated with the remittances' flow and consumption generated by it 301 .

After more than two decades of mass migration history, the recognition of Moldovan emigrants as "diaspora" took place only recently, illustrating the changes in the Moldovan state's strategies towards embracing these populations. The Moldovan Diaspora is structured in about 250 associations in over 30 countries, including different groups of initiative and professional excellence (most of them registered in Italy, Romania, Ukraine, the Russian Federation, Portugal, France, USA and Canada) 302.

Diaspora associations and groups are categorized as important actors who could take the role developing strategic activities in the area of migration and development, advocacy for promotion of image of Moldova in economic, cultural and investments areas and social sector as well.

It is obvious that globally, the impact of Diasporas on public institutions and policies becomes more complex and comprehensive, as Diasporas grow more organized, vocal and visible. This is also the case of Moldovan Diaspora's course. Therefore, Moldovan Government initiated a process of developing action plans, policies involving the mainstreaming of diaspora affairs within the portfolio of the relevant government stakeholders, so called in nowadays as "diasporisation" 303 . Respectively, the article will elaborate on some of the most recent interventions of Moldova in its efforts to mainstream migration into development and involve its young Diaspora.

\section{„Diaspora diplomacy”: measures, interventions and outreach practices}

There is growing international recognition of the importance of linkages between diaspora and development. Between the 1990s and early 2000s, the term Diaspora was usually discussed within the framework of globalization and accepted as an expression of identity in flux. The old notion of seeing a Diaspora as an outflow of human resources, or an exodus of skilled people and part of a brain drain, was replaced with the idea that Diasporas can indeed act as a bridge between countries of residence and origin. The institutionalisation of "diaspora diplomacy" is part of a wider trend and an indication for the fact that a country's diaspora community has

\footnotetext{
301 The Development Strategy “Moldova 2020” was adopted in 2016, za: www.gov.md. (12.11.2019). 302 The National Strategy “Diaspora 2025” was adopted in 2015, za: www.brd.gov.md (12.11.2019).

303 The term "diasporisation" is used in this article with the meaning given by the Ireland based consultancy company, Diaspora Matters - that government institutions develop a programme or project to engage their specific target audience (e.g. students, artists, athletes, highly skilled workers) while working towards a harmonised overall diaspora engagement approach.
} 
become considerably more important as a subject of interest for foreign policy and associated government activities. Moldova also joined this trend. The country started to view its diaspora as a "soft power" resource and new programs and outreach practices have been initiated to engage diaspora as agents of diplomatic and development goals.

This process involved reforms at strategic, policymaking and institutional levels, developing already some good practices in this regard. "Labour migration class" transformed into a "young Moldovan Diaspora members" who started to become not only bearers of culture and diversity, but also of development.

At strategic level, Moldovan Government acknowledged diaspora's importance and commits itself to be the promotor and defender of all citizens' rights, regardless of their place of residence, as well as to be an enabler of diaspora mobilization. The processes of formation of the young Moldovan diaspora were latent, disguised, because the integration of migrants in the countries of destination was not obvious. Most Moldovan migrant workers were irregular migrants. They arrived in (entered) the countries of their destination legally, on the basis of a tourist visa or other legal documents, but remained and worked in the country of destination illegally.

Therefore, Moldova focuses its migration governance efforts in two directions: diaspora engagement and safer labour migration. The Government has recognized the need for a coordinated and integrated approach to manage migration through harnessing remittances and youth emigration, as stated in the National Strategy on Migration and Asylum 2011-2020.304 According to the National Development Strategy Moldova 2030 (approved in 2018), the main pillars for development includes sustainable and inclusive economy; robust human and social capital 305. The strategy centred on the idea of capitalizing the potential of each Moldovan living inside and outside country.

Moreover, more national strategies and action plans have started to integrate the migration and development nexus. The Action Plan for Reintegrating Returning Migrants for 2018-2020 reveal the efforts of state institutions aimed to "capitalizing on the potential of migration for sustainable development". The National Strategy "Diaspora 2025" comes to underline that "national policies refocused from migration control to exploring the new global approaches on diaspora and migration as key elements for development". The interventions necessary for mainstreaming migration into the national development should be focused on promoting, strengthening, and extending different forms of diaspora's contributions. The formulation of the National Employment Strategy and its Action Plan for 2017-2021, managed to integrate aspects of diaspora engagement, to make migration's development impacts more tangible.

Moldova has made considerable progress in enhancing its data collection endeavours on migration through its government-led Extended Migration Profiles. So far, under the auspices of the Moldovan Bureau for Migration and Asylum, six editions of Extended Migration Profiles306 have been updated and used to inform policymaking. The Migration Profile exercise include a special chapter on mapping Diaspora and collect data on diaspora's members and their activities.

\footnotetext{
304 Strategy on Migration and Asylum 2011-2020, za: https://www.ilo.org/dyn/natlex/docs/ELECTRONIC/96973/114865/F431749726/HG_Strategia\%20nationala\%2 0in\%20domeniul\%20migr\%20si\%20azilul.pdf (12.11.2019).

305 The National Development Strategy 2030, approved in 2018.

306 Extended Migration Profile of Moldova, za: http://bma.gov.md/ro/documente/modele-de-documente (12.11.2019).
} 
In total, following the implementation of the migration mainstreaming mechanism in Moldova, 17 new migration relevant law reforms/new laws/strategies/action plans were elaborated and implemented307.

At institutional level, significant reforms were undertaken in the last few years. Moldovan Diaspora started to articulate its demands and interests to the Moldovan authorities. Following this process of exchange, was created the Bureau for Diaspora Relations in 2012 and further an Inter-Ministerial Committee on Diaspora, Migration and Development (DMD) at central level, which ensured intra-governmental coordination and policy coherence. The migration mainstreaming mechanism was also extended to the local level, with DMD committees established in more than 130 communities.

The institutional reform has given a significant incentive to the development and implementation of various programs, action plans, projects, and financial and intellectual support from international structures, organizations and platforms.

At international and regional levels, Moldova started intensely to participate in global fora dedicated to analyze migration and development nexus. Moldova's active participation in GFMD during the last years also offered the opportunity to engage in the international dialogue of the Global Compact for Migration and contribute to the efforts on the implementation of the Sustainable Development Goals of the 2030 Agenda for Sustainable Development.

Moldova was one of the pilot country of the EU-Moldova Mobility Partnership, signed in 2008. The results and best practices, lessons learnt, also encounters and rapid changes of the migration agenda during a decade of implementation were reflected in the evolution of the Mobility Partnership. If at the initial stage, projects under this Partnership focused on border management and legal migration, lately the initiatives redirected to Migration and Development nexus. The Partnership offered some good practices engaging Diaspora and innovative approaches. European Union referred to the Mobility Partnership with Moldova as an opportunity, which offered concrete outcomes trough 110 implemented projects, in this regard Moldova becoming a model for other states308. Moldova is also one of the most active beneficiary of the Mobility Partnership Facility instrument, funded by the EU and implemented by ICMPD, under which, for instance, has piloted social entrepreneurship and circular migration schemes, with the support of Italy.

At operational level, Moldova managed to initiate a few programs with engaging Diaspora, which proved to be efficient and rewarding, as the following.

The Diaspora Engagement Hub launched in 2016 is a governmental program for Moldovan citizens who have been resident for at least two years abroad and are highly qualified experts who wish to cooperate with representatives of governmental institutions on five priority areas: social, economic, environment/ecology/rural development, justice, civil society. It offers

\footnotetext{
307 IOM evaluation based on the developed Migration Governance Framework (MiGOF) in 2015 aimed to help countries to define what "well-managed migration policy" might look like at the national level. The Migration Governance Indicators (MGI) are meant to assist countries operationalize the MiGOF by using a standard set of approximately 90 indicators which could be applied across six key policy domains.

308 For more details and reference please access the website of the Moldovan Ministry of Foreign Affairs and European Integration which acts as the focal point for the EU-Mobility Partnership with Moldova, za: http://www.mfa.gov.md/mobility-partnership-en/ (12.11.2019).
} 
thematic grants for the citizens abroad, including diaspora associations and initiative groups309.

Program Pare $1+1$ is a National Program on Attracting Remittances into the Economy, launched in 2010310 . It is designed to attract remittances into the economy through the mobilization of migrants savings, stimulating small and medium enterprises (SMEs) development, supporting job creation especially at the local level. The program is implemented by the rule " $1+1$ ", which states that every Moldovan leu (local currency) invested from remittances will be matched with a leu from PARE. Applicants of the program could be migrant workers and/or their first-degree relatives. The maximum grant amounts is 200 thousand Moldovan lei (around 12.500 EUR). In 2018, the Moldovan government decided to extend the program by another three years by 2021 . So far, under the Program, were financed, assisted in business plan implementation \& monitored about 1348 SMEs and were allocated a total amount of $12 \mathrm{mln}$. EUR of grants. Each 1 Moldovan Leu from the Program generated 3,23 MDL investments in economy. However, one of the issue of the program is the monitoring and evaluation, which focuses largely on quantitative indicators (the evaluation is carried out during 2 years after the granting) and also major dependence on external sources of financing. The program was launched with the support of EU funding and further implemented with state budgetary support (partially). It helped to create instead new jobs, new businesses for Moldova such as almond cultivation, ostrich and snail growth, others, and many other success stories 311

Program DAR 1+3 is foreseen for the period 2019-2025 and aims to utilize the human and financial potential of the Diaspora in the socio-economic development of the country. The Programme is based on the $1+3$ principles of the partnership: Diaspora + government and/or local authorities + development partners and donors. The projects for granting should focus on infrastructure (water and sanitation, roads, schools, kindergartens); protection of the environment (pollution prevention, waste management); economy (investment, agriculture); optimization of energy (solar panels, street lighting, thermal insulation); culture (heritage, resting areas, rural tourism, exhibitions and festivals); education (children's programs, sports, innovation); social protection (medical centers, social centers, soup kitchens, etc.).

Program D.O.R (Diaspora. Origin. Return) started to be organized in 2013, on annual basis, a summer camp. DOR editions helped to strengthen the cultural ties of the diaspora children with the country of origin. During seven days, the program participants are involved in various thematic workshops and activities to learn more about culture and national traditions.

Diaspora Professional Return is a program offering grants to diaspora professional and highly-skilled migrants, encouraging the transfer of human capital and professional experience oriented towards the academic, social and economic development of Moldova, via short-term professional returns ( 2 weeks - 2 months).

309 BRD (2020): The Diaspora Engagement Hub. It was developed by Bureau for Diaspora Relations (BRD) in partnership with the IOM and the financial support of the Swiss Agency for Development and Cooperation. More information on the program, za: http://brd.gov.md/ro/content/diaspora-engagement-hub-1 (13.11.2019).

310 The Program was started with financial support of EU and is implemented by ODIMM - Organization for the Development of Small and Medium Enterprises, which operates in cooperation with the Ministry of Economy, local public authorities, business associations, business support providers, SMEs, za: https://odimm.md/en/aboutus. (10.11.2019).

311 An article on success stories on Program PARE $1+1$ and short video, za: https:/www.euneighbours.eu/en/east/eu-in-action/stories/moldova-pare-11-encouraging-migrants-return-home (12.11.2019). 
At policy level, Moldovan stakeholders undertake various actions to encourage Diaspora's participation in policymaking and decision making processes. For example, Diaspora Days is a platform organized since 2014 every year in August, under the Government's patronage. This includes a series of activities: Open Doors Day for the Diaspora at the Government; thematic seminars and consultations with the Diaspora; business forums; cultural and gastronomic events organised for the natives who returned home (crafts exhibitions, tasting of traditional food, master classes on pottery, weaving and cooking); Diaspora children camps youth camps (E-way to home) etc. At the thematic seminars, participants were focusing on economic programs and opportunities to promote the migrants' return and sustainable reintegration, nostalgic tourism, consultations on the National Development Strategy Moldova 2030 etc.

Another example is the efforts of Moldovan embassies to organise thematic roundtables on a regular basis and invite diaspora members to discuss recent socio-economic developments in Moldova (business forum of Diaspora).

Social security protection measures for migrant's trough negotiating and concluding bilateral agreements with destination countries is one of the most vivid examples of policy interventions. These agreements aim to offer protection of human rights of its citizens abroad and a package of social rights. Moldova signed so far 13 bilateral agreements with the main countries of residence in EU and CSI. In many cases, active Diaspora association could be agents of advocacy in concluding such agreements and facilitate the negotiation process.

With regard to remittances, which is a crucial component of migration and development nexus in Moldova, could be mentioned the following practice. It was created a system for transfer of remittances involving the National Postal Office and foreign counterparts, which was pilot-tested in one payment corridor (Italy-Moldova), and is currently under negotiation for further expansion to other payment corridors 312 . To be noted that Italy is the main country of destination for Moldovan citizens from EU.

Lately it is promoted diaspora / nostalgic tourism to Moldova, via organisation of festivals, national holidays, tourist routes, the development and pilot-testing of a Tourist Passport and the coordination of efforts from state agencies and service providers from the tourist sector.

The development of a cooperation mechanism involving private partners in this sector is at its inception phase, but should be definitely consolidated further and find new ways of engaging entrepreneurs or other private actors for this process.

One of the interesting policy intervention is at educational level. It was recently elaborated a concept and curricula for a comprehensive and sustainable training programme on migration and development, pilot-testing of a practitioner-oriented curriculum on migration and development, pilot-testing of two academic curricula with two handbooks produced (500 copies), and the production, publication and dissemination of various guides, handbooks and handout materials. The action is inspired by the global practices and recommendations in the international discourse on migration. The civil society (MADE) calls government to increase and develop national curricula that incorporate migration histories and anti-discrimination policies313.

312 Moldova: overview, za: http://www.migration4development.org/en/projects/profiles/moldova (07.11.2019). 313 MADE - Civil society Migration and Development network - following the set of 10 recommendations to come out of the Civil Society Days of the 2015 Global Forum on Migration and Development (GFMD) and launch of Global Diaspora Days in 2016 - for reference, za: https://madenetwork.org/global-diaspora-day (12.11.2019). 
Circular migrantion schemes under labour migration agreements are another example of policy interventions towards harnesing migration into development. Currently, there are implemented two bilateral agreements on labour migration which provides functional circular migration schemes for Moldovan Diaspora - Israel in Bulgaria. Moldovan citizens have the possibility to work for a determined period of time, with a legal labour contract and return home. One of the practical tool towards operationalization of circular migration schemes represented NEXUS Moldova Action which was the first prototype of an integrated and durable migration services provider specifically designed to support circular migration. It was designed to offer practical guidance and services on all stages of migration from a wide range of public, private and civil sector partners. It opened 6 local centres in Moldovan districts offering counselling on migration path from pre-departure stage to returning (during 2012-2017). It also includes a virtual service centre to provide access to online services from anywhere.

The above-mentioned interventions could illustrate Moldovan diaspora diplomacy at its inception phase, trying to use diplomatic and state authorities, to promote the systematic relationship, for mutual benefit, between the country of origin government, diaspora associations in countries of residence.

It was noted in recent studies that, Moldovan migrants perceive often Diaspora associations not only as ethno cultural, but also as social, human rights, information and consultative structures that can help with job, employment and various social issues. A large part of associations have managed to become an important source of information for Moldovan migrants, to promote Moldova abroad, its traditions and customs, to maintain relations with migration services from the countries of destination, to cooperate with various social stakeholders. For example, the services provided by the Diaspora organizations from Portugal are the most frequently used. According to national Strategy on "Diaspora 2025" the interventions necessary for mainstreaming migration into the national development should be focused on promoting, strengthening, and extending different forms of diaspora's contributions, as: support Diaspora associations in EU Member States to provide better services, in close cooperation with central and local public administration of the countries of origin and countries of residence. This emphasize that Diaspora could also be pro-active and consolidate its efforts and align to Government policies for a better result in the development process of the country .

\section{Diaspora engagement: challenges and the way forward}

The public policies and good practices of Diaspora outreach and contributions reflect the interest of the Moldova to harness its migration towards development, following the international experiences. However, considering the political crisis and economic instability of the country, engaging Diaspora remains challenging and needs further efforts towards its successful path.

A stringent challenge remains the lack of trust in the political institutions in Moldova, considering the ongoing severe political crisis, which affects the motivation of Diaspora members. State institutions dealing with diaspora and development sectors should build up the relations and continuously and open communicate with Diaspora groups. Despite the fact that serious institutional reforms in this regard have been done by Moldovan Government, more coherence and synergies would be needed. Bureau for Relations with Diaspora is relatively a young institution and requires for capacity building interventions.

One of the shortages is the fragmented character of the Moldovan Diaspora and its insufficient capacity in advocacy, which could be developed further. There is a need to enable Diaspora associations with operational capacities, to have an increased role, to act more structured and organized. 
Another problem is dependency on the international funding dedicated to different migration and development projects, which diminish the ownership of initiatives. There are practices of developing pilot initiatives with the support of international assistance which are handled further to state budgeting and planning. These should serve as good examples for next steps. Projects like PARE 1+1, Migrants circular schemes, Extended Migration Profile became Government-led after its pilot phase.

Monitoring and evaluation of different diaspora outreach practices, its impact should be also improved, and more qualitative indicators could be developed further.

Key Message. Diaspora engagement for development is not a unilateral process depending only on Government policies. This should be a multilateral and open dialogue, involving the state, media, civil society and development partners and Diaspora itself and should change the community's mind-set and perception of the migration phenomenon and cultivate positive and constructive approaches at every stage of migration process.

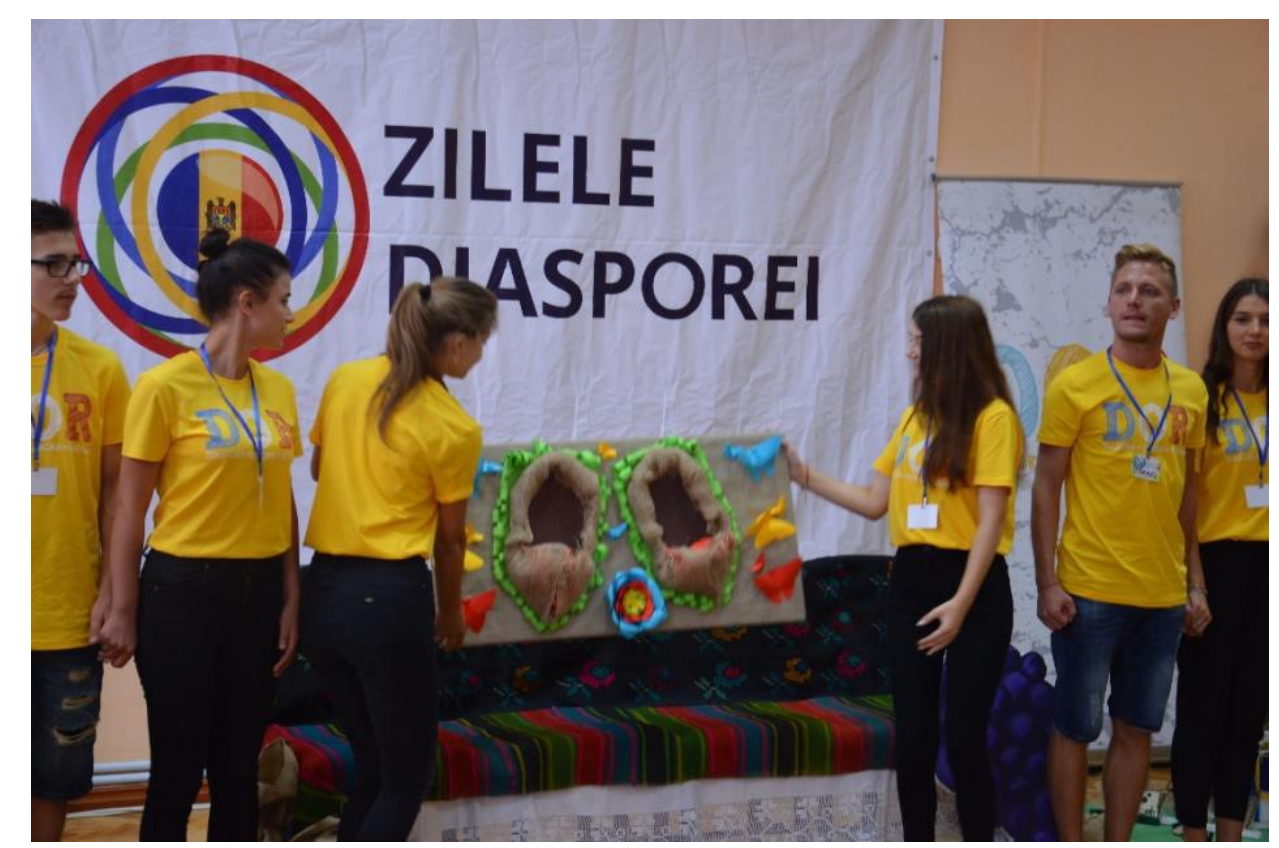

Image from DOR program dedicated to Diaspora Children - summer camp

\section{Streszczenie:}

Obecnie na poziomie globalnym wpływ diaspor na instytucje publiczne i polityki staje się coraz bardziej złożony i kompleksowy. Wynika to z faktu, iż diaspory stają się coraz bardziej zorganizowane i widoczne. Tak jest również w przypadku mołdawskiej diaspory. Kilka lat temu rząd Mołdawii zainicjował proces opracowywania planów działania, polityk obejmujących włączanie spraw diaspory do głównego nurtu działań odpowiednich instytucji rządowych, zwanych obecnie "diasporyzacją". W niniejszym artykule zostaną omówione niektóre z najnowszych działań Mołdawii w jej wysiłkach na rzecz włączenia migracji do głównego nurtu rozwoju. Teskt zawiera krótką analizę reform podjętych przez rząd i członków 
jego młodej diaspory $\mathrm{w}$ celu zwiększenia ich wzajemnego zaangażowania na poziomie strategicznym, prawnym, politycznym i instytucjonalnym. W artykule zostaną zaprezentowane nie tylko najlepsze praktyki w zakresie prób angażowania diaspory, ale także wnioski wyciągnięte $\mathrm{z}$ tego dynamicznego procesu, na rzecz dalszej dyskusji na ten temat - diaspory $\mathrm{i}$ rozwoju oraz dalszych działań w tym kierunku.

\section{Słowa klucz:}

Diaspora, migracja i rozwój, migracja na rzecz rozwoju, dyplomacja diaspor, polityka migracyjna

\section{Keywords:}

Diaspora, Migration and Development, Mainstream migration into development, Diaspora Diplomacy, Migration policy

\section{Bibliografia:}

1. Cheianu-Andrei D., Chisinau 2013 - Mapping the Moldovan diaspora in Italy, Portugal.

2. Extended Migration Profile of Moldova 2010-2015.

3. France and the United Kingdom of Great Britain and Northern Ireland.

4. Migration Governance Snapshot: The Republic of Moldova, IOM, May 2018 assessed by MGI initiative, which is a policy-benchmarking programme, led by the IOM and implemented with the support of the Economist Intelligence Unit.

5. Moldova: overview - Global hub on migration and development, the M4D Net, za: http://www.migration4development.org/en/projects/profiles/moldova.

6. National Development Strategy 2030 of Moldova (2018) za: https://gov.md/sites/default/files/document/attachments/intr40_12_0.pdf.

7. National "Diaspora 2025" za: http://brd.gov.md/sites/default/files/sn_diaspora_2025_web.pdf.

8. National Strategy on Management of Migration and Asylum 2011-2020.

9. Remittances on track to become the largest source of external financing in developing countries, World Bank, 2019. 